\title{
BIOLOGY
}

\section{Micromorphology and anatomy of the flower of Tulbaghia Violacea Harv. (Amaryllidaceae)}

\author{
O. S. Fishchuk \\ Lesya Ukrainka Volyn national university \\ Corresponding author. E-mail: dracaenaok@ukr.net
}

Paper received 13.12.20; Accepted for publication 23.12.20.

\section{https://doi.org/10.31174/SEND-NT2020-244VIII30-02}

Abstract. The external morphology and micromorphology of the flower in Tulbaghia violacea were studied. Light microscopy was used for examination. Our approach allows us to differentiate species and genera by location and presence of different vertical zones in gynoecium and especially septal nectaries. The gynoecium of $T$. violacea consists of synascidiate, symplicate, hemisymplicate and asymplicate vertical zones. Common septal nectary with three nectary splits throughout the ovary is available in T. violacea gynoecium.

Keywords: ovary, gynoecium, septal nectary, flower morphology.

Introduction. Modern molecular taxonomy in the branches construction of relationship between families and genera doesn't take into consideration the morphological features of flowers and fruit, even if it takes into account, it's not a lot. Molecular taxonomy doesn't take into account the features of the internal structure of the gynoecium and the fruits, its zonality and the septal nectary structure. The scientists are looking for new morphological features, features of flower vascular anatomy and they are studing the morphogenesis (formation and opening of the fruit) of the flower-fruit system. It is very important to study not only the flower features but also the fruit morphological features because some morphological features of the fruit are laid at the flower stage. We should study flower features in the post-anthetic phase, because studying the fruit capsule, for example, it is impossible to study the ways of its formation without studying the flower structure.

Brief overview of related publications. Modern morphologists are increasingly studying the flower and fruit morphology and anatomy in monocotyledons for further using them of the identified features in the taxonomy [1,2, 7, 18, 19, 22, 26, 27, 28, 29]. The family Amaryllidaceae is the subject of extensive research in molecular phylogeny and evolution [12, 13, 14, 15, 16]. According to modern molecular-phylogenetic taxonomy, the genus Tulbaghia belongs to the family Amaryllidaceae, subfamily Allioideae, tribe Tulbaghieae [5].

Tulbaghia violacea is the subject of a great deal of scientific work. Particularly known generalized data from ethnobotany, pharmacology, phytochemistry and conservation needs [3], studied influence of temperature and watering frequencies on seed germination and seedling growth of Tulbaghia violacea [8], researched tomato spotted wilt virus identified in Tulbaghia violacea [6], studied gene transfer utilizing pollen-tubes Tulbaghia violacea [10], the effect of storage and processing on antimicrobial activity of Tulbaghia violacea [25], antagonistic effect of cadmium on micronutrients of Tulbaghia violacea [9], investigated the chemical composition of the volatile compounds from aerial parts of Tulbaghia violacea Harv. was studied by GC and GC/-MS [24], development a micropropagation protocol for variegated Tulbaghia violacea 'Silver Lace', using appropriate growth regulators and cultural methods which will retain the variegated phenotype [23].
Aim. Describing the internal structure of gynoecium in T. violacea we used the concept of vertical zonality by $\mathrm{W}$. Leinfelner [11]. This concept implies the existence of two types of syncarpous gynoecium, The eusyncarpous and hemisyncarpous gynoecium, the last one characterized by congenital growth in the lateral part of the column, its gynoecium has three vertical zones: hemisynascidiate, hemisymplicate and asymplicate and sometimes has septal nectary. It is very important to study the morphological features and gynoecium vertical zones, as these data can be used for the taxonomy of monocotyledons.

Material and methods. The flowers of $T$. violace were studied in the stage of the floral bud and opened flower. The material was collected in agrobiostation of the Lesya Ukrainka Volyn National University (Lutsk) and fixated in $70 \%$ ethanol. Out of the fixated material we prepared the preparations of a series of cross-sections of the flowers of $20 \mu \mathrm{m}$ thick, using the standard method [4]. The sections were stained using astra blue solutions and safranine.

We studied five flowers of this species. To describe the preparations we used a Laboval 4 optical microscope manufactured by Carl Zeiss (Jena) and a stereosco-pic binocular microscope MBS-10.

To analyze the internal structure of the gynoecium, we used the concept of vertical zonation of gynoecia of Leinfellner (1950) [11]. which takes into consideration only the congenital fusion of the carpels. According to this concept, with growth of the carpels, in the syncarpous gynoecium, congenital multi-locular synascidiate, unilocular simplicate, transitional hemi-simplicate and asymplicate (apocarpous) zones form. In the conditions of incomplete fusion of carpels, a hemi-syncarpous gynoecium with hemisynascidiate, hemisimplicate and asymplicate zones form only in their external part. The height of the zones of gynoecium was measured according to the number of cross sections. The methodological basis of study of the vertical zonation of the gynoecium was formulated by Leinfellner (1950), later the method was elaborated for monocots [17, 20, 21].

Results. The flowers of $T$. violace a are up to $2.2-2.3 \mathrm{~cm}$ long, slightly zygomorphic, purple, have a strong garlic smell. The peduncle is up to $35-37 \mathrm{~cm}$ long and $0.5 \mathrm{~cm}$ in diameter at the base and $0.4 \mathrm{~cm}$ in diameter at the top, 1520 flowers in the inflorescence. There are two cone-shaped bracts, leathery, light brown up to $2.2 \mathrm{~cm}$ long, $0.9 \mathrm{~cm}$ wide 
at the base and $0.6 \mathrm{~cm}$ wide and the other one $2.8 \mathrm{~cm}$ long, $0.5 \mathrm{~cm}$ wide at the base and $0.7 \mathrm{~cm}$ wide. The pedicel up to $2.1 \mathrm{~cm}$ long, about $0.1 \mathrm{~cm}$ in diameter.

The flowers have funnel-shaped floral tube, short, about $1.1-1.2 \mathrm{~cm}$ long, $0.3 \mathrm{~cm}$ in diameter. The outer tepals are $1.1 \mathrm{~cm}$ long, $0.4-0.45 \mathrm{~cm}$ wide, and the inner tepals are 1 $\mathrm{cm}$ long and $0.4-0.5 \mathrm{~cm}$ wide, respectively. The tepals at the end of the floral tube have outgrowth in the form of an inverted horseshoe, resembling a crown.

There are six stamens, fastened to the floral tube. The stamen filaments are very short, attached inside the floral tube. The outer stamens are located below, the inner stamens are $0.4 \mathrm{~cm}$ higher. The outer and inner stamens have stamen filaments up to $0.05 \mathrm{~cm}$ long and $0.1 \mathrm{~cm}$ in diameter. The anthers are arcuate, introse, dorsifixed, the anthers in the external stamens are $0.1 \mathrm{~cm}$ long and the anthers in the inner stamens are $0.15 \mathrm{~cm}$ long and $0.05 \mathrm{~cm}$ in diameter.

The gynoecium is very short, $0.4 \mathrm{~cm}$ long. The ovary is upper, bright green, inverted ovate, $0.25 \mathrm{~cm}$ high and 0.2 $\mathrm{cm}$ in diameter, which turns into a short column up to 0.1 $\mathrm{cm}$ long and $0.1 \mathrm{~cm}$ in diameter with trilobate stigma up to $0.05 \mathrm{~cm}$ in length and $0.1 \mathrm{~cm}$ in diameter.

In the upper part of the flower flowers, at the base of the flower tube, in the stamens and in the walls of tying the existing idioblasts with cellular inclusions - raffids. They are absent in the free tops of the perianth leaves, knitter and column.

The apical part of pedicel, the base of the flower tube, the stamen filaments and the wall of the ovary, contain idioblasts with cellular inclusions - raphides. They are absent in free apices of the tepals and in the style.

In the gynoecium T.violacea after W. Leinfellner (1950) [11], threre are four vertical zones synascidiate $-360 \mathrm{mkm}$, fertile symplicate $-300 \mathrm{mkm}$, hemisymplicate $-180 \mathrm{mkm}$, and asymplicate $-320 \mathrm{mkm}$ ). According to the newly created concept of septal nectary vertical zonation by Odintsova A.V. [21] for the eusyncarpous type of gynoecium, the following are distinguished: zone of distinct nectary with the postgenitally closed central part, zone of common nectary with the congenitally closed cavities of the nectary and the zone of external nectary where the septal grooves fuse with the nectariferous cavities.

Among monocotyledons, a common type of nectary is often found, which is characterized by the integration of nectar cavities with a common epidermis and the presence of free edges of the carpel. Distinct nectaries have not been widely studied [Одінцова]. Septal nectaries are represented by three distinct tariferous cavities at the base, they unite above and open on the surface of the ovary and the total height of the septal nectary in T.violacea is 500 $\mu \mathrm{m}$.

The pedicel contains 6 vascular bundles, upper they merges in a central cylinder. At the level of receptacle, they divided into traces of the tepals and dorsal bundles. In the center there is one big vascular bundle which even at the level of locules appearance does not branch. And only at the ovules appearance it is divided into three ventral crescent bundles - roots of a ventral complex which providing nutrition to the ovules with its ends formed 6 ventral bundles.

In each locule there are four ovules, the trace of ovules is one-bundle. Above the ventral bundles in pairs diverge along the partitions where over the nests merge with the dorsal bundles of the carpel and form a dorsal vein. Above the cells of the ovary, the ventral bundles of the carpel go in the septa and later unite with the dorsal bundles and form the dorsal vein. The traces of the outer tepals and traces of the inner tepals comprise 1 vascular bundles. The traces of the stamens are single-bundled and diveded from the traces of outer tepals and traces of the inner tepals at the levels of the floral tube first external traces and previous internal traces.

Conclusion. In the gynoecium of the studied species were found four vertical zones: synascidiate, symplicate, hemisymplicate and asymplicate. This gynoecium is hemisyncarpous sensu lato because it contains a hemisymplicate zone, but also has a synascidiate zone which is a characteristic of the eusyncarpous type of gynoecium. The style in $T$. violacea consists of asymplicate zone. The total height of the septal nectary is $500 \mu \mathrm{m}$ and it is consisits of distinct nectary cavities at the base of the ovary, common nectary zone with three nectary cavities united in the ovary centre and external where the septal grooves fuse with the nectariferous cavities. This type of zonality with gynoecium was not previously detected for species of the Tulbaghia genus.

The presence and height of different vertical zones of the ovary and septal nectary, as well as the interconnection of these two types of vertical zonality allow us to more accurately differentiate the study species in Amaryllidaceae family. And having researched these furthers of the fruit structure of the described representative, we will give an explanation of some morphological features that are laid down at the flower phase, because we are interested in the post-anthetic phase.

\section{REFERENCES}

1. Andreychuk R., Odintsova A. Actual state of carpological studies in the family Campanulaceae Juss. with regard to its systematics, Studia Biologica, 2020, 14(2). P. 95-116 (in Ukraine) DOI: $10.30970 /$ sbi.1402.616

2. Andreychuk R., Odintsova A. Morphological and anatomical structure of Campanula latifolia L. Fruits. Studia Biologica, 2019, 13(1). P. 95-105 DOI: 10.30970/sbi.1301.593

3. Aremu A. O., van Staden J. The genus Tulbaghia (Alliaceae) A review of its ethnobotany, pharmacology, phytochemistry and conservation needs // Journal of ethnopharmacology, 2013, 149(2). P. 387-400 DOI: 10.1016/j.jep.2013.06.046

4. Barykina R. P., Veselova T. D., Deviatov A. G. Djalilova H. H., Iljina G. M., Chubatova N. V. Handbook of the botanical microtechniques. Moscow Uni-versity Press, Moscow, 2004 (in Russian).

5. Chase M. W., Christenhusz M. J. M., Fay M. F., Byng J. W., Judd W. S., Soltis D. E., Mabberley D. J., Sennikov A. N., Soltis P. S., Stevens P. F. The angiosperm phylogeny group. An update of the angiosperm phylogeny group classification for the orders and families of flowering plants APG IV. Botanical Journal of the Linnean Society, 2016, 181. P. 1-20. doi:10.1111/boj.12385

6. Dey K., Li C., Sellers M. C., McVay J., Whilby L., Hodges G., Smith T. R. First Report of Tomato Spotted Wilt Virus Identified in Tulbaghia violacea in Florida // Plant Health Progress, 2019, 20(2). P. 131-131 DOI: 10.1094/PHP-03-19-0020-BR

7. Dyka O. Flower morphology and vascular anatomy in some representatives of Urgineoideae (Hyacinthaceae) // Thaiszia J. Bot., Košice, 2018, 28 (2). P. 125-143 
8. Kulkarni M.G., Shane Sparg, van Staden J. Influence of temperature and watering frequencies on seed germination and seedling growth of Ornithogalum longibracteatum and Tulbaghia violacea // Scientia Horticulturae, 2005, 107(1). P.103-109 DOI: 10.1016/j.scienta.2005.08.001

9. Kulkarni M.G., Southway C., A Stirk W., Vanstaden J. Antagonistic effect of cadmium on micronutrients of Tulbaghia violacea // South African Journal of Botany, 2008, 74(2). P. 390390 DOI: 10.1016/j.sajb.2008.01.156

10. Kumari A., Baskaran P., van Staden J. Gene transfer utilizing pollen-tubes of Albuca nelsonii and Tulbaghia violacea // Cropp Breeding and Applied Biotechnology, 2017, 17(3). P. 228-234 DOI: 10.1590/1984-70332017v17n3a35

11. Leinfellner W. Der Bauplan des syncarpen Gynoeceums / W. Leinfellner // Österr. Bot. Zeitschr. - 1950. - Bd. 97, H. 3-5. S. 403-436.

12. Meerow A. W., Guy C. L., Li Q.-B., Clayton J. R. Phylogeny of the Tribe Hymenocallideae (Amaryllidaceae) Based on Morphology and Molecular Characters. Annals of the Missouri Botanical Garden, 2002, 89 (3). P. 400413. doi:10.2307/3298600. JSTOR 3298600.

13. Meerow A. W., Snijman D. A. Phylogeny of Amaryllidaceae Tribe Amaryllideae Based on nrDNA ITS Sequences and Morphology. American Journal of Botany, 2001, 88 (12). P. 23212330. doi: $10.2307 / 3558392$. JSTOR 3558392.

14. Meerow A.W., Francisco-Ortega J., Schnell R.J. Phylogenetic relationships and biogeography within the Eurasian clade of Amaryllidaceae based on plastid ndhF and nrDNA ITS sequences: lineage sorting in a reticulate area? Systematic Botany, 2006, $31 \quad$ (1). $\quad$ P. 42-60. doi:10.1600/036364406775971787. JSTOR 25064128.

15. Meerow A.W., Guy C.L., Li Q.-B., Yang S.-L. Phylogeny of the American Amaryllidaceae Based on nrDNA ITS Sequences. Systematic Botany, 2000, 25 (4). P. 708726. doi:10.2307/2666729. JSTOR 2666729.

16. Meerow A.W., Fay M.F., Guy C.L., Li Q.-B., Zaman F.Q., Chase M.W. Systematics of Amaryllidaceae based on cladistic analysis of plastid rbcL and trnL-F sequence data. American Journal of Botany, 1999, $86(9)$. P. 13251345. doi:10.2307/2656780. JSTOR 2656780. PMID 104878 20.

17. Novikoff A., Odintsova A. Some aspects of gynoecium morphology in three bromeliad species. Wulfenia, 2008, 15, P. 1324.
18. Odintsova A, Fishchuk O. The flower morphology in three Convallariaceae species with various attractive traits // Acta Agrobotanica, 2017, 70(1). P. 1705-1719.

19. Odintsova A. Loculicidal dehiscence of superior and inferior capsular fruits in Myrtales Studia Biologica, 2016, 10(3-4). P. 129-140 (in Ukraine) DOI: 10.30970/sbi.1003.504

20. Odintsova A. Two principal models of monocots' septal nectaries Visnyk of the Lviv University. Series BIology. 2013, 61. P. 41-50 (in Ukraine)

21. Odintsova A. Vertical Zonality Of Septal Nectaries Of Monocots. Modern Phytomorphology, 2013,4: 317-318 (in Ukraine) DOI: 10.5281/zenodo.161409

22. Odintsova A., Fishchuk O., Sulborska A. The gynoecium structure in Dracaena fragrans (L.) Ker Gawl., Sansevieria parva N.E. Brown and Sansevieria trifasciata Prain (Asparagaceae s.1.) with special emphasis on the structure of the septal nectary. Acta Agrobotanica, 2013, 66 (4). P. 55-64.

23. Phelan S., Douglas G., Hunter A. Micropropagation and growth regulation of Tulbaghia violacea Silver Lace // Acta $\begin{array}{llll}\text { horticulturae, 2007, 764(764). P. 113-118 } & \text { P. }\end{array}$ DOI: $10.17660 /$ ActaHortic.2007.764.13

24. Pino J., Quijano C. E., Fuentes V.Volatile Compounds of Tulbaghia violacea Harv. // Journal of essential oil-bearing $\begin{array}{llll}\text { plants JEOP, 2013, 11(2). } & \text { P. 203-207 }\end{array}$ DOI: $10.1080 / 0972060 X .2008 .10643621$

25. Ranglova K., Krejčová P., Kubec R. The effect of storage and processing on antimicrobial activity of Tulbaghia violacea // South African Journal of Botany, 2015, 97. P. 159-164 DOI: 10.1016/j.sajb.2015.01.011

26. Skrypec K., Odintsova A. Anatomical Structure Of Pericarp In Gladiolus Imbricatus L. And Iris Sibirica L. (Iridaceae). Modern Phytomorphology, 2014, 6. P. 257-258 (in Ukraine) DOI: 10.5281/zenodo.160774

27. Skrypec K., Odintsova A. Fruit and seed morphology in Iris sibirica L. and Gladiolus imbricatus L. in relation with the modes of dissemination Biological systems, 2015, 7(1). P. 93 (in Ukraine)

28. Skrypec K., Odintsova A. Morphogenesis of fruits in Gladiolus imbricatus and Iris sibirica (Iridaceae). Ukrainian Botanical Journal, 2020, 77(3). P. 210-224 (in Ukraine) DOI: $10.15407 /$ ukrbotj77.03.210

29. Skrypec K., Odintsova A. New data on pollination of Iris sibirica L. (Iridaceae). Studia Biologica, 2014, 8(3-4). P. 197208 (in Ukraine) DOI: 10.30970/sbi.0803.383 